\title{
Syntheses of Radioiodinated Pyrimidine-2,4,6-Triones as Potential Agents for Non-Invasive Imaging of Matrix Metalloproteinases
}

\author{
Hans-Jörg Breyholz ${ }^{1}$, Klaus Kopka ${ }^{2}$, Michael Schäfers ${ }^{3}$ and Stefan Wagner ${ }^{1, *}$ \\ 1 Department of Nuclear Medicine, University Hospital Münster, Albert-Schweitzer-Campus 1, Building A1, \\ D-48149 Münster, Germany; hans-joerg.breyholz@ukmuenster.de \\ 2 Division of Radiopharmaceutical Chemistry, German Cancer Research Center (DKFZ), \\ Im Neuenheimer Feld 280, D-69120 Heidelberg, Germany; k.kopka@dkfz-heidelberg.de \\ 3 European Institute for Molecular Imaging (EIMI), University of Münster, Waldeyerstraße 15, \\ D-48149 Münster, Germany; michael.schaefers@ukmuenster.de \\ * Correspondence: stefan.wagner@ukmuenster.de; Tel.: +49-251-83-44713
}

Academic Editor: Jean Jacques Vanden Eynde

Received: 8 May 2017; Accepted: 28 May 2017; Published: 30 May 2017

\begin{abstract}
Dysregulated expression or activation of matrix metalloproteinases (MMPs) is observed in many kinds of live-threatening diseases. Therefore, MMP imaging for example with radiolabelled MMP inhibitors (MMPIs) potentially represents a valuable tool for clinical diagnostics using non-invasive single photon emission computed tomography (SPECT) or positron emission tomography (PET) imaging. This work includes the organic chemical syntheses and in vitro evaluation of five iodinated barbiturate based MMPIs and the selection of derivative 9 for radiosyntheses of isotopologues $\left[{ }^{123} \mathrm{I}\right] 9$ potentially useful for MMP SPECT imaging and $\left[{ }^{124} \mathrm{I}\right] \mathrm{9}$ for MMP PET imaging.
\end{abstract}

Keywords: pyrimidine-2,4,6-triones; radioiodination; matrix metalloproteinase inhibitor; fluorometric in vitro inhibition assays

\section{Introduction}

The in vivo molecular imaging of locally upregulated and activated matrix metalloproteinases (MMPs) that are observed in pathologies such as cardiovascular diseases, inflammation or cancer remains a substantive clinical issue [1]. Current targeting strategies for noninvasive imaging of MMPs should not only account for high binding affinity and specificity towards the enzyme but also for drug-target residence time [2], subgroup selectivity, sensitivity, target-to-background ratio as well as in vivo stability [3]. Maybe insufficient consideration of these parameters caused that most of the preclinical studies of the past 20 years with radiolabeled MMPIs were either disappointing or remained at a preliminary stage $[4,5]$. In addition an inadequate validation of the animal models regarding their level of MMP expression leads to challenging data [6].

Our own approaches towards the development of radiolabelled and fluorescent-dye conjugated MMP tracers focused on two different classes of non-peptidic MMPIs, on the one hand hydroxamate-based inhibitors (i.e., derivatives of CGS 27023A and CGS 25966 [7] with a broad-spectrum inhibitory profile) and, on the other hand, pyrimidine-2,4,6-trione-based inhibitors (i.e., barbiturates, derivatives of RO-2653 [8-11] with sub-group selectivity for the gelatinases A (MMP-2) and B (MMP-9), neutrophil collagenase (MMP-8) and the membrane-bound MMPs MT-1-MMP (MMP-14) and MT-3-MMP (MMP-16)). Initially, in 2005 we suggested in the latter project a first radiolabelled barbiturate-based MMPI, compound 12 (see Table 2) labelled with the radionuclide iodine-125 $\left({ }^{125} \mathrm{I}\right)$, for first in vitro and 
ex vivo applications [12]. In 2008 we developed for the first time the barbiturate-based near-infrared fluorescent photo probe Cy5.5-AF443 that was suitable for in vitro and in vivo imaging of the gelatinases MMP-2 and MMP-9 [13,14]. In 2010 we published the radiosynthesis and evaluation of the first fluorine-18 $\left({ }^{18} \mathrm{~F}\right)$ labelled barbiturate-based MMPI [15] and two years later, of several more hydrophilic radiofluorinated analogues with improved biodistribution behavior [16]. Moreover, a gallium-68 $\left({ }^{68} \mathrm{Ga}\right)$ labelled version was introduced by our group in 2012 [17]. Favorable MMP binding affinities for our barbiturate-based tracers were indeed measured by in vitro assays and in vivo biodistribution studies using wt-mice. However, in animal models with increased MMP expression mentioned barbiturate-based tracers did not meet the expectations. Anyhow in vivo MMP imaging was feasible and specific with our hitherto most encouraging optical imaging probe Cy5.5-AF443 suggesting the assumption that improved imaging performance of the photoprobe Cy5.5-AF443 compared to the barbiturate radiotracers is caused by the cyanine dye substituent with the four hydrophilic sulfonic acid moieties. Actually, these structural characteristics change the physicochemical properties and accordingly the essential biodistribution pattern influenced i.a. by the excretion routes (renal or hepatobiliary), plasma-protein binding, binding to non-target-organs and/or off-target interactions with other proteins. In summary, adopting or transferring features from optical tracers to radiotracers could support their development, an aspect that was recently reviewed by Faust et al. [18]. Therefore, the aim of this work was the synthesis of radioiodinated barbiturate-based MMPI tracers with increased hydrophilicity for potential SPECT/PET imaging. Radionuclides iodine-123 and iodine-124 were used for the radiosyntheses and applied on our target molecule 9, which is ca. 3 log units more hydrophilic as compared to our initial preclinical research tracer $\left[{ }^{125} \mathrm{I}\right] \mathbf{1 2}$ (see Table 2) [12]. To achieve increased hydrophilicity two different chemical modifications of the C5 phenoxyphenyl moiety in 12 that occupies the S1' enzyme pocket were realized. Moreover the commercially available radionuclides iodine-123 (for SPECT) and iodine-124 (for PET) exhibit prolonged half-lives $t \frac{1}{2}$ compared to the most common $\gamma$-emitter for SPECT technetium-99m ( $t \frac{1}{2} 13.2 \mathrm{~h}$ vs. $\left.6.0 \mathrm{~h}\right)$ and $\beta^{+}$-emitter for PET fluorine-18 ( $\mathrm{t}_{1 / 2} 4.2 \mathrm{~d}$ vs. $110 \mathrm{~min}$ ) allowing long-term studies with the corresponding ${ }^{123 / 124} \mathrm{I}$-labelled barbiturate-based tracer in the next steps.

\section{Results and Discussion}

\subsection{Chemistry}

Phenyl barbiturates 5a-d and $\mathbf{6}$ were prepared as outlined in Scheme 1 by four- (compounds 5a-c), five- (compound 5d) or six-step (compound 6) sequences, respectively.

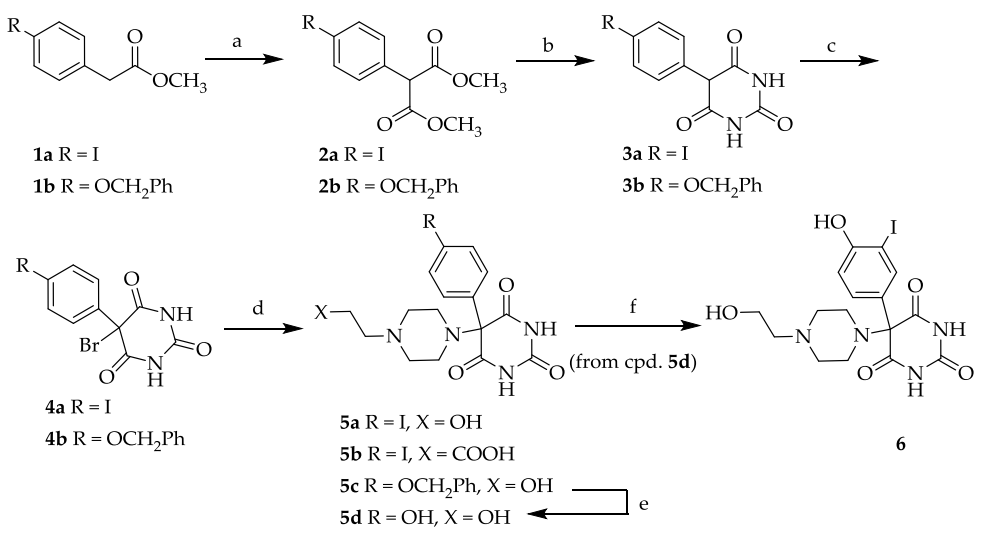

Scheme 1. Syntheses of phenyl barbiturates 5a-d and 6. Reagents and yields: (a) NaH, dimethyl carbonate, dioxane, 82\% (2a), 73\% (2b); (b) urea, NaOEt, EtOH, 29\% (3a), 91\% (3b); (c) NBS, dibenzoyl peroxide, $\mathrm{CCl}_{4}, 51 \%$ (4a); $\mathrm{Br}_{2}, \mathrm{HBr}, \mathrm{H}_{2} \mathrm{O}, 89 \%$ (4b); (d) $\mathrm{N}$-(2-hydroxyethyl)-piperazine or 3-(piperazin-1-yl)-propionic acid, $\mathrm{MeOH}, 53 \%$ (5a), 18\% (5b), 28\% (5c); (e) $\mathrm{H}_{2}, \mathrm{Pd} / \mathrm{C}, \mathrm{MeOH}, 82 \%$ (5d); (f) $\mathrm{NaI}, \mathrm{NaOCl}, \mathrm{NaOH}, \mathrm{MeOH}, 12 \%$ (6). 
In detail, 4-iodophenyl acetic acid methylester (1a), synthesized by the esterification of commercial 4-iodophenyl acetic acid using $\mathrm{MeOH} / \mathrm{H}_{2} \mathrm{SO}_{4}$ was methoxycarbonylated to give the corresponding malonic ester 2a. 4-Benzyloxyphenyl malonic acid dimethyl ester (2b) [19] was obtained from methyl 2-((4-benzyloxy)phenyl)acetate (1b) [20] analogous to 2a by the literature procedure. Malonic esters $\mathbf{2} \mathbf{a}$ and $\mathbf{2} \mathbf{b}$ were cyclized with urea using sodium ethoxide as a base to yield the 5-phenylbarbituric acid derivatives $\mathbf{3} \mathbf{a}$ and $\mathbf{3} \mathbf{b}$, which subsequently were brominated with $N$-bromosuccinimide (NBS) (compound $\mathbf{3 a}$ ) or bromine/ $\mathrm{HBr}$ (compound $\mathbf{3 b}$ ), resulting in the 5-bromo-5-phenyl barbituric acids $4 \mathbf{a}$ and $\mathbf{4 b}$. These were reacted with either of the commercially available piperazines $\mathrm{N}$-(2-hydroxyethyl)-piperazine or 3-(piperazin-1-yl)-propionic acid in $\mathrm{MeOH}$ to yield the barbituric acid derivatives $5 \mathbf{a}-\mathrm{c}$ in overall yields of $6 \%(5 \mathbf{a}), 2 \%(5 \mathbf{b})$ and $17 \%(5 \mathrm{c})$. Cleavage of the benzyloxy group in $\mathbf{5 c}$ was achieved by catalytic hydrogenation $\left(\mathrm{H}_{2}, \mathrm{Pd} / \mathrm{C}, \mathrm{MeOH}\right)$ resulting in the hydroxyl compound $5 \mathrm{~d}$ in $14 \%$ overall yield. Iodination of $5 \mathrm{~d}$ using sodium iodide, sodium hypochlorite and sodium hydroxide in methanol yielded the ortho iodination product 6 in $2 \%$ overall yield.

To obtain carboxy derivative 9 and fluoro derivative $\mathbf{1 0}$ (Scheme 2) the bromo intermediate $\mathbf{7 ,}$ whose synthesis was described previously [12], was reacted either with commercially available 3-(piperazin-1-yl)-propionic acid or piperazine 8 [15]. The yields were $83 \%$ for 9 and $8 \%$ for $\mathbf{1 0}$ (Scheme 2).
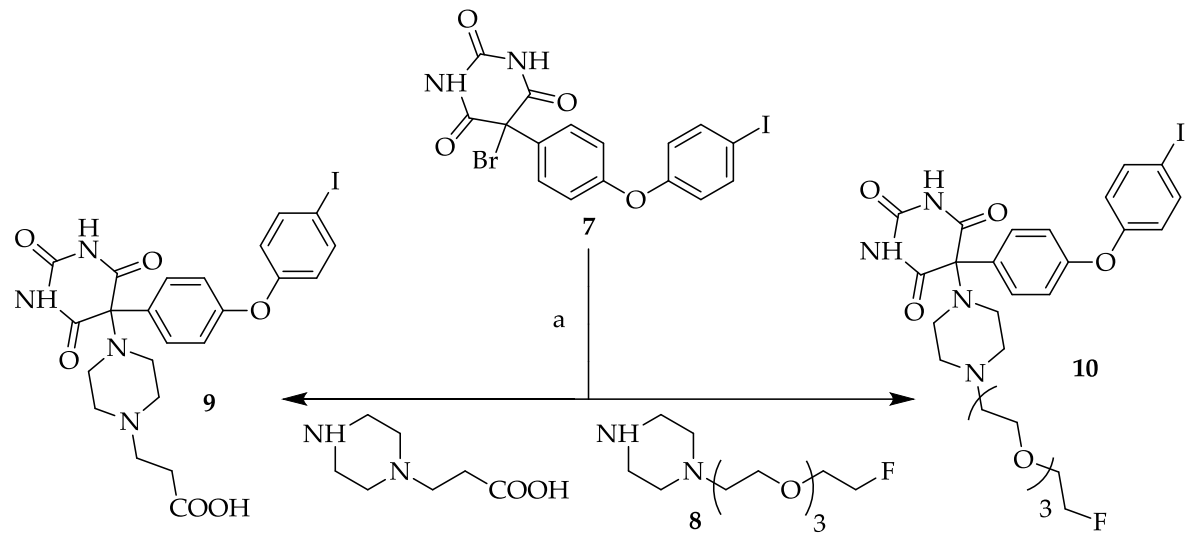

Scheme 2. Syntheses of compounds 9 and 10. Reagents and yields: (a) $\mathrm{MeOH}, 83 \%$ (9), 8\% (10).

\subsection{Enzyme Assays and $\log D$ Values}

The MMP inhibition potencies of the barbituric acid derivatives $5 a, 5 b, 6,9$ and 10 were measured in fluorometric in vitro inhibition assays as described previously [21]. The $\mathrm{IC}_{50}$-values of $\mathbf{5 a}, \mathbf{5 b}$ and $\mathbf{6}$ were determined for gelatinases MMP-2 and MMP-9 (Table 1), the $\mathrm{IC}_{50}$-values of $\mathbf{9}$ and $\mathbf{1 0}$ for MMP-2, MMP-8, MMP-9, MMP-13 and MMP-14 (only 9) (Table 2). The results are depicted in Tables 1 and 2. The tables also contain the calculated $\log \mathrm{P} / \log \mathrm{D}$ values $(\log \mathrm{P} / \operatorname{cog} \mathrm{D})$ of the synthesized barbituric acids derivatives to indicate the changes of lipophilicities caused by the structural modifications.

Replacement of the phenoxyphenyl moiety in $\mathbf{1 2}$ (see Table 1) by a phenyl group resulted in compounds $\mathbf{5 a - d}$ and $\mathbf{6}$. As expected the lipophilicities of iodinated $\mathbf{5 a}-\mathbf{b}$ and $\mathbf{6}$ are significantly reduced, with clogD values ranging between -1.34 and 1.26 compared to 12 with a clogD value of 3.53. On the other hand the $\mathrm{IC}_{50}$ values for MMP-2 and -9 of these compounds are generally increased compared to the derivatives with a phenoxyphenyl residue (Table 2). This is also expected because the phenoxyphenyl core is optimized for the deep and narrow $S_{1}{ }^{\prime}$ pocket of the target MMPs [8]. While $\mathbf{5 b}$ and 6 possess $\mathrm{IC}_{50}$ values for MMP-2 and -9 in the micromolar range (0.67-1.6 $\mu \mathrm{M}$, Table 1$), 5 \mathrm{a}$ is at least a potent MMP-2 inhibitor with an $\mathrm{IC}_{50}$ value of $10 \mathrm{nM}$. 
Table 1. $\mathrm{IC}_{50}$ values of phenyl barbiturates $5 \mathbf{a}, 5 \mathbf{b}$ and 6 .<smiles>[R]c1ccc(C2([R3])C(=O)NC(=O)NC2=O)c([R])c1</smiles>

\begin{tabular}{|c|c|c|c|c|c|c|c|}
\hline \multirow{2}{*}{ Cpd. } & \multirow{2}{*}{$\mathbf{R}_{1}$} & \multirow{2}{*}{$\mathbf{R}_{2}$} & \multirow{2}{*}{$\mathbf{R}_{3}$} & \multicolumn{4}{|c|}{$\mathrm{IC}_{50}[\mathrm{nM}]$} \\
\hline & & & & MMP-2 & MMP-9 & $\operatorname{clog} P^{a}$ & $\operatorname{clog} \mathrm{D}^{\mathrm{a}}$ \\
\hline $5 a$ & $-\mathrm{I}$ & $-\mathrm{H}$ & & $10 \pm 3$ & $550 \pm 180$ & 1.42 & 1.26 \\
\hline $5 b$ & $-\mathrm{I}$ & $-\mathrm{H}$ & & $1200 \pm 340$ & $1600 \pm 600$ & -0.85 & -1.34 \\
\hline 6 & $-\mathrm{OH}$ & $-\mathrm{I}$ & & $670 \pm 210$ & $1300 \pm 320$ & 0.75 & 0.53 \\
\hline
\end{tabular}

a $\operatorname{cog} \mathrm{P} / \operatorname{cog} \mathrm{D}$ values were calculated by $\mathrm{ACD} /$ Chemsketch version $\mathrm{ACD} / \mathrm{Labs} 6.00(\operatorname{cog} \mathrm{D}=\operatorname{clog} \mathrm{P}$ at physiological $\mathrm{pH}$ (7.4) with consideration of charged species). Values are the mean \pm standard deviation (SD) of three assays.

Table 2. Structures and $\mathrm{IC}_{50}$ values of phenoxyphenyl barbiturates 9-12.<smiles>[R]c1ccc(Oc2ccc(C3([R2])C(=O)NC(=O)NC3=O)cc2)cc1</smiles>

\begin{tabular}{|c|c|c|c|c|c|c|c|c|}
\hline \multirow{2}{*}{ Cpd. } & \multirow{2}{*}{$\mathbf{R}_{1}$} & \multirow{2}{*}{$\mathbf{R}_{2}$} & \multicolumn{6}{|c|}{$\mathrm{IC}_{50}[\mathrm{nM}]$} \\
\hline & & & MMP-2 & MMP-8 & MMP-9 & MMP-13 & $\operatorname{clog} P^{a}$ & $\operatorname{clog} \mathrm{D}^{\mathrm{a}}$ \\
\hline $9^{b}$ & $-\mathrm{I}$ & & $29 \pm 2$ & $1170 \pm 80$ & $1.3 \pm 0.2$ & $362 \pm 24$ & 1.40 & 0.92 \\
\hline 10 & $-\mathrm{I}$ & & $23 \pm 5$ & $146 \pm 48$ & $17 \pm 5$ & $28 \pm 11$ & 3.13 & 2.99 \\
\hline 12 & $-\mathrm{I}$ & & $7 \pm 1$ & n. d. & $2 \pm 0.2$ & n. d. & 3.68 & 3.53 \\
\hline $13^{c}$ & $-\mathrm{H}$ & & $23 \pm 9$ & $138 \pm 12$ & $7 \pm 2$ & $645 \pm 17$ & 3.17 & $2.88^{\mathrm{d}}$ \\
\hline
\end{tabular}

${ }^{a} \operatorname{cog} \mathrm{P} / \operatorname{cog} \mathrm{D}$ values were calculated by $\mathrm{ACD} /$ Chemsketch version $\mathrm{ACD} / \mathrm{Labs} 6.00(\operatorname{cog} \mathrm{D}=\operatorname{cog} \mathrm{P}$ at physiological $\mathrm{pH}$ (7.4) with consideration of charged species). Values are the mean $\pm \mathrm{SD}$ of three assays. ${ }^{\mathrm{b}} \mathrm{IC}_{50}(\mathrm{MMP}-14)=49 \pm 8 \mathrm{nM}^{\mathrm{c}}{ }^{\mathrm{I}} \mathrm{IC}_{50}(\mathrm{MMP}-1)>50 \mu \mathrm{M}, \mathrm{IC}_{50}(\mathrm{MMP}-3)=760 \mu \mathrm{M}$. ${ }^{\mathrm{d}}$ experimental $\log \mathrm{D}=2.15 \pm 0.02$. For comparison reasons the $\mathrm{IC}_{50}$ values of compound 12 [12] and 13 [15] from previous work are also shown.

The second hydrophilic modification included the substitution of the hydroxy group with a carboxy group in the piperazine residue of $\mathbf{1 2}$ to yield carboxylic acid $\mathbf{9}$ resulting in a clogD shift of 2.6 units (approximately 400 fold increased water solubility, Table 2) from 3.53 towards 0.92 . Despite this modification the high MMP-2- and -9-inhibition potency of $\mathbf{1 2}$ was only marginally influenced (Table 2, 12: $\mathrm{IC}_{50}(\mathrm{MMP}-2)=7 \mathrm{nM}, \mathrm{IC}_{50}(\mathrm{MMP}-9)=2 \mathrm{nM} .9: \mathrm{IC}_{50}(\mathrm{MMP}-2)=29 \mathrm{nM}$, $\left.\mathrm{IC}_{50}(\mathrm{MMP}-9)=1.3 \mathrm{nM}\right)$. Moreover, in vitro data showed, that 9 was also a nanomolar inhibitor of collagenase 3 (MMP-13) and MMP-14 (MT-1 MMP), but only a micromolar inhibitor of neutrophil collagenase $(\mathrm{MMP}-8)\left(9:\left(\mathrm{IC}_{50}(\mathrm{MMP}-14)=49 \mathrm{nM}\right.\right.$ (Table 2, footnote b), $\mathrm{IC}_{50}(\mathrm{MMP}-8)=1170 \mathrm{nM}$, $\left.\mathrm{IC}_{50}(\mathrm{MMP}-13)=362 \mathrm{nM}\right)$. In summary, compound 9 confirms the results from Grams et al. [8] that 5,5-disubstituted barbiturates with a para-substituted phenoxyphenyl unit represent potent inhibitors for MMP-2, -9 and -14. Additionally, as shown by comparison of the $\mathrm{IC}_{50}$ values of $\mathbf{9}$ and $\mathbf{1 3}$ with $\mathbf{1 0}$ the elongation of the substituent of the piperazine residue with fluorinated tri-ethylenglycol resulted in a 
decrease of selectivity for unknown reasons. From this selection of iodinated barbiturate derivatives carboxylic acid 9 was chosen for radiochemical synthesis of the radioiodinated isotopologues $\left[{ }^{123 / 124} \mathrm{I}\right] \mathbf{9}$ (see Section 2.3) because this compound possesses the most favourable characteristics indicated by $\operatorname{cog} \mathrm{D}$ and $\mathrm{IC}_{50}$-values.

\subsection{Radiochemistry}

Palladium-catalyzed cross-coupling reaction (Stille coupling) of non-radioactive reference compound 9 with tributyltin hydride (or hexabutylditin) (yield: $28 \%$ ) [20] provided the stannyl precursor 11 (Scheme 3).
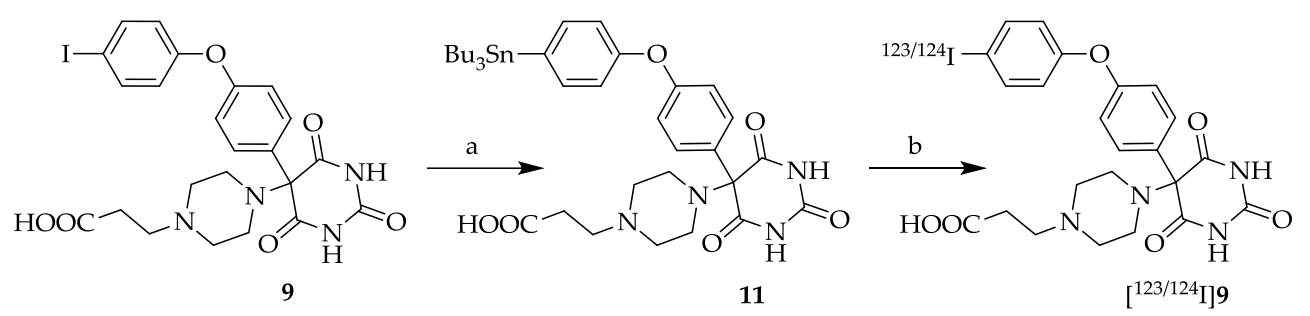

Scheme 3. Precursor synthesis of $\mathbf{1 1}$ and radiosynthesis of the barbituric acid-based MMP-targeted model tracer [ $\left.{ }^{123 / 124} \mathrm{I}\right]$ 9. Reagents and yields: (a) $\mathrm{Bu}_{3} \mathrm{SnH}$ or $\mathrm{Bu}_{6} \mathrm{Sn}_{2}$ (2.0 eq.), $\mathrm{PdCl}_{2}\left(\mathrm{PMePh}_{2}\right)_{2}$ or $\mathrm{PdCl}_{2}$ (3 mol\%), KOAc (3.0 eq.), N-methyl-pyrrolidone, 28\%; (b) [ $\left.{ }^{123 / 124} \mathrm{I}\right] \mathrm{NaI}$, chloroamine-T hydrate, $0.1 \mathrm{M} \mathrm{K}_{2} \mathrm{HPO}_{4}$.

Subsequent radioiododestannylation of $\mathbf{1 1}$ with no-carrier-added (n. c. a.) [ $\left.{ }^{123 / 124} \mathrm{I}\right] \mathrm{NaI}$ and chloroamine-T led to the radioligands $\left[{ }^{123 / 124} \mathrm{I}\right] 9$. The decay-corrected radiochemical yields were $28 \pm 7 \%(n=6)$ for $\left[{ }^{123} \mathrm{I}\right] 9$ and $44 \pm 6 \%(n=3)$ for $\left[{ }^{124} \mathrm{I}\right] 9$ at the end of synthesis (EOS) and the radiochemical purities were $95 \pm 3 \%$ for $\left[{ }^{123} \mathrm{I}\right] 9$ and $93 \pm 5 \%$ for $\left[{ }^{124} \mathrm{I}\right] 9$ (as determined by radio-HPLC). The molar activities are $0.2-6.3 \mathrm{GBq} / \mu \mathrm{mol}$ and $0.4-14.0 \mathrm{GBq} / \mu \mathrm{mol}$, respectively. The identities of $\left[{ }^{123 / 124} \mathrm{I}\right] 9$ were proven by HPLC (coinjection and coelution with reference compound 9 ).

\section{Materials and Methods}

\subsection{General Methods. Chemistry}

All chemicals, reagents and solvents for the synthesis of the compounds were of analytical grade, purchased from commercial sources and used without further purification, unless otherwise specified. Melting points were determined in capillary tubes on a SMP3 capillary melting point apparatus (Stuart Scientific, Staffordshire, UK) and are uncorrected. ${ }^{1} \mathrm{H}-\mathrm{NMR},{ }^{13} \mathrm{C}-\mathrm{NMR}$ and ${ }^{19} \mathrm{~F}-\mathrm{NMR}$ spectra were recorded on ARX 300 and/or AMX 400 spectrometers (Bruker, Karlsruhe, Germany). $\mathrm{CDCl}_{3}$ contained tetramethylsilane (TMS) as an internal standard. Mass spectra were obtained on a MAT 212 $(\mathrm{EI}=70 \mathrm{eV})$ spectrometer (Varian Medical Systems, Palo Alto, CA, USA) and a Bruker MALDI-TOF-MS Reflex IV instrument (matrix: DHB). Exact mass analyses were conducted on a Quattro LC (Waters, Milford, MA, USA) and a Bruker MicroTof apparatus. Elemental analyses were realized by a Vario EL III analyzer (Elementar Analysensysteme Comp., Hanau, Germany). All aforementioned spectroscopic and analytical investigations were done by staff members of the Institute of Organic Chemistry, University of Münster, Germany. All purifications of compounds and determinations of purity by HPLC were performed by using a gradient RP-HPLC system (Knauer, Berlin, Germany) equipped with two K-1800 pumps, an S-2500 UV detector and RP-HPLC Nucleosil Eurosphere 100-10 C-18 columns for analytical $(250 \mathrm{~mm} \times 4.6 \mathrm{~mm})$ purposes. The following eluents were used (unless specified otherwise): eluent A: water ( $0.1 \%$ TFA), eluent B: acetonitrile ( $0.1 \%$ TFA). The following conditions were used (unless specified otherwise): Gradient from $90 \%$ A to $20 \%$ A over 30 min, constant $20 \%$ A over $5 \mathrm{~min}$ and from $20 \%$ A to $90 \%$ A over $5 \mathrm{~min}$, at a flow rate of $1.5 \mathrm{~mL} / \mathrm{min}$, detection at $\lambda=254 \mathrm{~nm}$. 
3.2. General Procedure for 4-Iodophenyl Malonic Acid Dimethyl Ester (2a) and 4-Benzyloxyphenyl Malonic Acid Dimethyl Ester (2b)

A suspension of $4.00 \mathrm{~g} \mathrm{NaH}$ (166 mmol, $6.66 \mathrm{~g}$ of a $60 \%$ suspension in paraffin; the paraffin was removed by repeated washings with petroleum benzene) and $48.0 \mathrm{~g}$ (533 mmol) dimethyl carbonate in $80 \mathrm{~mL}$ absolute dioxane was heated to $100-120^{\circ} \mathrm{C}$ and a solution of $23.00 \mathrm{~g}(83.3 \mathrm{mmol})$ 4-Iodophenyl acetic acid methylester (1a, prepared by the esterification of 4-iodophenyl acetic acid using $\left.\mathrm{MeOH} / \mathrm{H}_{2} \mathrm{SO}_{4}\right)$ in absolute dioxane $(125 \mathrm{~mL})$ was added dropwise over a period of $1 \mathrm{~h}$. Refluxing was continued for $3 \mathrm{~h}$ and the reaction mixture was allowed to come to room temperature overnight. The mixture was poured onto ice water and subsequently extracted with methylene chloride $(3 \times)$. The combined organic layers were washed with water $(1 \times)$, brine $(1 \times)$, dried $\left(\mathrm{Na}_{2} \mathrm{SO}_{4}\right)$ and concentrated. The crude $\mathbf{2 a}$ was used in the next step without further purification. Yield: $22.8 \mathrm{~g}$ (68.2 mmol, 82\%). ${ }^{1} \mathrm{H}-\mathrm{NMR}\left(300 \mathrm{MHz}, \mathrm{DMSO}-\mathrm{d}_{6}\right): \delta[\mathrm{ppm}]: 7.90\left(\mathrm{~d},{ }^{3} \mathrm{~J}=8.3 \mathrm{~Hz}, 2 \mathrm{H}, \mathrm{H}_{\text {Aryl }}\right), 7.35$ $\left(\mathrm{d},{ }^{3} \mathrm{~J}=8.3 \mathrm{~Hz}, 2 \mathrm{H}, \mathrm{H}_{\text {Aryl }}\right), 5.18(\mathrm{~s}, 1 \mathrm{H}, \mathrm{CH}), 3.83$ (s, $\left.6 \mathrm{H}, \mathrm{CH}_{3}\right) .{ }^{13} \mathrm{C}-\mathrm{NMR}\left(75.5 \mathrm{MHz}, \mathrm{DMSO}-d_{6}\right)$ : $\delta$ [ppm]: 168.46, 138.14, 133.10, 131.88, 94.86, 55.99, 53.11. 4-Benzyloxyphenyl malonic acid dimethyl ester (2b) [19] was prepared from methyl 2-((4-benzyloxy)phenyl)acetate 1b [20] analogous to 2a.

\subsection{General Procedure for 5-(4-Iodophenyl)-pyrimidine-2,4,6-trione (3a) and 5-(4-Benzyloxyphenyl)-pyrimidine-2,4,6-trione (3b)}

Under an argon atmosphere 2 eq. of sodium were dissolved in ethanol $(0.35 \mathrm{~mL} / \mathrm{mmol} \mathrm{Na})$ and 1.7 eq. of urea were added. A solution of malonic ester $\mathbf{2 a}$ or $\mathbf{2} \mathbf{b}$ in ethanol $(2.2 \mathrm{~mL} / \mathrm{mmol})$ was added dropwise and the reaction mixture was heated to reflux for $6 \mathrm{~h}$. After cooling to room temperature, the mixture was poured onto ice water and adjusted to $\mathrm{pH} 2$ using dilute hydrochloric acid. The precipitate was collected by suction and dried in vacuo. 3a: Yield: $29 \% .{ }^{1} \mathrm{H}-\mathrm{NMR}(300 \mathrm{MHz}$, DMSO-d ) $: \delta$ [ppm]: 11.34 (broad, s), 7.68 (broad, d, 2 H, H Aryl), 7.09 (broad, d, 2 H, H Aryl $_{\text {) }}, 4.92$ (s, 1 H, $\mathrm{CH}) .{ }^{13} \mathrm{C}-\mathrm{NMR}$ (75.5 MHz, DMSO- $\left.d_{6}\right): \delta$ [ppm]: 187.77 (C-4/6 enol form), 169.73 (C-4/6 keto form), 151.31 (C-2), 137.41, 132.46, $128.89,93.48,92.09$ (C-5 enol form), 54.60 (C-5 keto form). Anal. Calcd for $\mathrm{C}_{10} \mathrm{H}_{7} \mathrm{IN}_{2} \mathrm{O}_{4}$ : C 36.39, H 2.14, N 8.49. Found: C 36.61, H 2.29, N 8.23. 3b: Yield: 91\%. Mp $233-236{ }^{\circ} \mathrm{C}$. ${ }^{1} \mathrm{H}-\mathrm{NMR}\left(300 \mathrm{MHz}, \mathrm{DMSO}-d_{6}\right): \delta$ [ppm]: 11.34 (broad, s, OH), 7.4-6.94 (m, $\left.9 \mathrm{H}, \mathrm{H}_{\text {Aryl }}\right), 5.10$ (s, $1 \mathrm{H}$, $\mathrm{CH}) .{ }^{13} \mathrm{C}-\mathrm{NMR}$ (75.5 MHz, DMSO- $\left.d_{6}\right): \delta$ [ppm]: 187.75 (C-4/6 enol form), 169.71 (C-4/6 keto form), 158.25, 151.29 (C-2), 137.39, 132.44, 130.64, 128.14, 115.31, 114.36, 92.06 (C-5 enol form), 69.58, 54.59 (C-5 keto form). Anal. Calcd for $\mathrm{C}_{10} \mathrm{H}_{14} \mathrm{IN}_{2} \mathrm{O}_{4} \cdot \mathrm{H}_{2} \mathrm{O}$ : C 62.19, $\mathrm{H}$ 4.91, N 8.53. Found: C 62.38, H 4.56, N 8.14.

\subsection{5-Bromo-5-(4-iodophenyl)-pryrimidine-2,4,6-trione (4a)}

A suspension of $3 \mathrm{a}(6.51 \mathrm{~g}, 19.7 \mathrm{mmol}), \mathrm{N}$-bromosuccinimide $(4.20 \mathrm{~g}, 23.6 \mathrm{mmol}, 1.2 \mathrm{eq}$.$) and$ a catalytic amount of dibenzoylperoxide in carbon tetrachloride $(400 \mathrm{~mL})$ was heated to reflux for a period of $3 \mathrm{~h}$. After cooling to room temperature the mixture was concentrated, the residue was treated with water and extracted with ethyl acetate $(3 \times)$. The combined extracts were washed with brine, dried $\left(\mathrm{Na}_{2} \mathrm{SO}_{4}\right)$ and the solvent was evaporated. The residue was stirred in $\mathrm{CHCl}_{3}$ for $2 \mathrm{~h}$ to give a colorless solid. Yield: $4.10 \mathrm{~g}$ (10.0 mmol, 51\%). Mp 183-186 ${ }^{\circ} \mathrm{C} .{ }^{1} \mathrm{H}-\mathrm{NMR}\left(300 \mathrm{MHz}, \mathrm{DMSO}-\mathrm{d}_{6}\right)$ : $\delta$ [ppm]: 11.47 (broad, s), 10.94 (broad, s), 8.64 (broad, s), 7.71 (d, 2 H, H Aryl $), 7.15$ (d, 2 H, H Aryl $)$. ${ }^{13}$ C-NMR (75.5 MHz, DMSO- $\left.d_{6}\right): \delta$ [ppm]: 179.66, 170.80, 137.81, 133.18, 127.65, 95.76, 75.99. MS (EI): m/e (intensity \%): 410 ( $\left.\mathrm{M}^{+}, 15\right), 408\left(\mathrm{M}^{+}, 15\right), 329$ (100), 282 (45), 244 (45), 196 (62), 129 (29), 89 (38), 43 (39). Anal. Calcd for $\mathrm{C}_{10} \mathrm{H}_{6} \mathrm{BrIN}_{2} \mathrm{O}_{3}$ : C 29.37, H 1.48, N 6.85. Found: C 29.96, H 1.48, N 6.80.

\subsection{5-(4-Benzyloxyphenyl)-5-bromo-pryrimidine-2,4,6-trione (4b)}

A suspension of the $3 \mathbf{b}(5.00 \mathrm{~g}, 16.1 \mathrm{mmol})$ in water $(48 \mathrm{~mL})$ was cooled to $0-5{ }^{\circ} \mathrm{C}$ and $48 \% \mathrm{HBr}$ $(3.25 \mathrm{~mL}, 28.4 \mathrm{mmol})$ and bromine $(1.32 \mathrm{~mL}, 25.8 \mathrm{mmol})$ were added dropwise. After stirring for $4-5 \mathrm{~h}$ at $0-10{ }^{\circ} \mathrm{C}$ the precipitate was collected by filtration and dried in vacuo. Yield: $5.59 \mathrm{~g}(14.4 \mathrm{mmol}, 89 \%)$. Mp 145-147 ${ }^{\circ} \mathrm{C} .{ }^{1} \mathrm{H}-\mathrm{NMR}\left(300 \mathrm{MHz}, \mathrm{DMSO}-d_{6}\right): \delta$ [ppm]: 11.44 (broad, s), 7.43-7.01 (m, $9 \mathrm{H}, \mathrm{H}_{\text {Aryl }}$ ), $5.08\left(\mathrm{~s}, 2 \mathrm{H}, \mathrm{CH}_{2}\right) .{ }^{13} \mathrm{C}-\mathrm{NMR}\left(75.5 \mathrm{MHz}, \mathrm{DMSO}-d_{6}\right): \delta$ [ppm]: 171.34, 159.00, 150.21, 137.18, 130.86, 
128.79, 128.03, 127.99, 126.88, 115.30, 76.28, 69.70. MS (ESI-EM) m/e: $410.9951(\mathrm{M}+\mathrm{Na})^{+}$calcd for $\mathrm{C}_{17} \mathrm{H}_{13} \mathrm{BrN}_{2} \mathrm{O}_{4} \mathrm{Na}$ 410.9956. Anal. Calcd for $\mathrm{C}_{17} \mathrm{H}_{13} \mathrm{BrN}_{2} \mathrm{O}_{4} \cdot 0.3 \mathrm{H}_{2} \mathrm{O}: \mathrm{C}$ 52.10, H 3.42, N 7.15. Found: C 51.79, H 3.12, N 6.96.

\subsection{General Procedure for Compounds $\mathbf{5 a - 5 \mathbf { c }}$}

A solution of $4 \mathbf{a}$ or $4 \mathbf{b}$ in methanol $(2-4 \mathrm{~mL} / \mathrm{mmol})$ was treated with 2 eq. of $N$-(2-hydroxyethyl)piperazine (in case of $\mathbf{5 a}$ and $\mathbf{5 c}$ ) or 3-(piperazin-1-yl)-propionic acid (in case of $5 \mathbf{b}$ ) and stirred for $2 \mathrm{~d}$ at room temperature. The colorless precipitate was collected by suction and dried in vacuo.

\subsubsection{5-[4-(2-Hydroxyethyl)piperazin-1-yl]-5-(4-iodophenyl)pryrimidine-2,4,6-trione (5a)}

Yield: 53\%. Mp 168-172 ${ }^{\circ} \mathrm{C} .{ }^{1} \mathrm{H}-\mathrm{NMR}\left(400 \mathrm{MHz}, \mathrm{DMSO}-d_{6}\right): \delta[\mathrm{ppm}]: 7.72\left(\mathrm{~d},{ }^{3} \mathrm{~J}=8.7 \mathrm{~Hz}, 2 \mathrm{H}\right.$, $\left.\mathrm{H}_{\text {Aryl }}\right), 7.16\left(\mathrm{~d},{ }^{3} \mathrm{~J}=8.7 \mathrm{~Hz}, 2 \mathrm{H}, \mathrm{H}_{\text {Aryl }}\right), 3.43-2.31\left(\mathrm{~m}, 12 \mathrm{H}, \mathrm{CH}_{2}\right) .{ }^{13} \mathrm{C}-\mathrm{NMR}\left(75.5 \mathrm{MHz}, \mathrm{DMSO}-d_{6}\right)$ : $\delta$ [ppm]: 169.36, 151.07, 138.72, 131.17, 130.13, 95.72, 85.71, 59.68, 58.20, 53.59, 47.24. MS (ESI-EM) m/e: $459.0518(\mathrm{M}+\mathrm{H})^{+}$calcd for $\mathrm{C}_{16} \mathrm{H}_{20} \mathrm{IN}_{4} \mathrm{O}_{4} 459.0524$. Anal. Calcd for $\mathrm{C}_{16} \mathrm{H}_{19} \mathrm{IN}_{4} \mathrm{O}_{4} \cdot \mathrm{H}_{2} \mathrm{O}: \mathrm{C} 40.35$, H 4.23, N 11.76. Found: C 40.93, H 4.54, N 11.47.

\subsubsection{5-[4-(2-Carboxyethyl)piperazin-1-yl]-5-(4-iodophenyl)pyrimidine-2,4,6-trione (5b)}

Yield: $18 \%$. Mp $139-142{ }^{\circ} \mathrm{C} .{ }^{1} \mathrm{H}-\mathrm{NMR}\left(300 \mathrm{MHz}, \mathrm{DMSO}-d_{6}\right): \delta$ [ppm]: 9.42 (broad, s), $8.00(\mathrm{~d}$, $\left.{ }^{3} J=8.7 \mathrm{~Hz}, 2 \mathrm{H}, \mathrm{H}_{\text {Aryl }}\right), 7.61\left(\mathrm{~d},{ }^{3} \mathrm{~J}=8.7 \mathrm{~Hz}, 2 \mathrm{H}, \mathrm{H}_{\text {Aryl }}\right), 3.30-3.21\left(\mathrm{~m}, 4 \mathrm{H}, \mathrm{CH}_{2}\right), 2.85-2.59(\mathrm{~m}, 8 \mathrm{H}$, $\left.\mathrm{CH}_{2}\right) .{ }^{13} \mathrm{C}-\mathrm{NMR}\left(75.5 \mathrm{MHz}\right.$, DMSO- $\left.d_{6}\right): \delta$ [ppm]: 173.74, 164.25, 151.49, 138.89, 135.07, 131.70, 86.35, 85.64, 53.23, 49.47, 43.38, 32.01. MS (ESI-EM) $m / e: 487.0453(\mathrm{M}+\mathrm{H})^{+}$calcd for $\mathrm{C}_{17} \mathrm{H}_{20} \mathrm{IN}_{4} \mathrm{O}_{5} 487.0473$. Anal. Calcd for $\mathrm{C}_{17} \mathrm{H}_{19} \mathrm{IN}_{4} \mathrm{O}_{5} \cdot 1.8 \mathrm{H}_{2} \mathrm{O}: \mathrm{C} 39.88, \mathrm{H}$ 4.04, N 10.80. Found: C 39.59, H 4.23, N 10.48.

\subsubsection{5-[4-(2-Hydroxyethyl)piperazin-1-yl]-5-(4-benzyloxyphenyl)pryrimidine-2,4,6-trione (5c)}

Yield: $28 \%$. Mp $211-213{ }^{\circ} \mathrm{C} .{ }^{1} \mathrm{H}-\mathrm{NMR}\left(400 \mathrm{MHz}, \mathrm{DMSO}-d_{6}\right): \delta[\mathrm{ppm}]: 7.48-7.02\left(\mathrm{~m}, 9 \mathrm{H}, \mathrm{H}_{\text {Aryl }}\right)$, 5.09 (s, $\left.2 \mathrm{H}, \mathrm{CH}_{2}\right), 3.48-3.44\left(\mathrm{~m}, 2 \mathrm{H}, \mathrm{CH}_{2} \mathrm{OH}\right), 2.57-2.38\left(\mathrm{~m}, 10 \mathrm{H}, \mathrm{CH}_{2}\right) .{ }^{13} \mathrm{C}-\mathrm{NMR}(100 \mathrm{MHz}$, DMSO- $\left.d_{6}\right): \delta$ [ppm]: 171.08, 159.63, 150.35, 137.67, 130.00, 129.32, 128.78, 128.28, 128.08, 115.76, 74.99, 70.26, 61.07, 59.28, 48.10, 44.91. MS (MALDI-TOF) $m / e: 461(\mathrm{M}+\mathrm{Na})^{+}, 439(\mathrm{M}+\mathrm{H})^{+}$. Anal. Calcd for $\mathrm{C}_{23} \mathrm{H}_{26} \mathrm{~N}_{4} \mathrm{O}_{5} \cdot 1 \mathrm{H}_{2} \mathrm{O}$ : C 60.52, H 6.18, N 12.27. Found: C 60.35, H 5.71, N 12.27.

\subsection{5-[4-(2-Hydroxyethyl)piperazin-1-yl]-5-(4-hydroxyphenyl)pryrimidine-2,4,6-trione (5d)}

Compound $5 \mathrm{c}(1.66 \mathrm{~g}, 3.79 \mathrm{mmol})$ was dissolved in absolute methanol $(150 \mathrm{~mL})$, treated with $\mathrm{Pd} / \mathrm{C}(10 \%, 250 \mathrm{mg})$ and heated to reflux for $12 \mathrm{~h}$ under an $\mathrm{H}_{2}$ atmosphere. After cooling to room temperature, the mixture was stirred overnight. The catalyst was filtered off and washed with methanol $(80 \mathrm{~mL})$. The solvent was evaporated and the solid residue was dried in vacuo. The crude product was taken up in a $\mathrm{CHCl}_{3} /$ ethylacetate mixture $(1 / 1, \mathrm{v} / \mathrm{v})$ and stirred at room temperature for $2-3 \mathrm{~h}$ and finally re-isolated by suction filtration. Yield: $1.08 \mathrm{~g}(3.11 \mathrm{mmol}, 82 \%)$. Mp $185{ }^{\circ} \mathrm{C}$. ${ }^{1} \mathrm{H}-\mathrm{NMR}(300 \mathrm{MHz}$, DMSO- $\left.d_{6}\right): \delta[\mathrm{ppm}]: 7.45\left(\mathrm{~d},{ }^{3} J=8.6 \mathrm{~Hz}, 2 \mathrm{H}, \mathrm{H}_{\text {Aryl }}\right), 7.03\left(\mathrm{~d},{ }^{3} J=8.6 \mathrm{~Hz}, 2 \mathrm{H}, \mathrm{H}_{\text {Aryl }}\right), 3.79(\mathrm{~m}, 2 \mathrm{H}$, $\left.\mathrm{CH}_{2} \mathrm{OH}\right), 2.99-2.69\left(\mathrm{~m}, 10 \mathrm{H}, \mathrm{CH}_{2}\right) .{ }^{13} \mathrm{C}-\mathrm{NMR}\left(75.5 \mathrm{MHz}, \mathrm{DMSO}-d_{6}\right): \delta$ [ppm]: 170.66, 158.47, 149.82, 131.22, 129.29, 115.94, 74.63, 59.74, 57.66, 53.73, 46.67. MS (ESI-EM) $m / e: 349.1521(\mathrm{M}+\mathrm{H})^{+}$calcd for $\mathrm{C}_{16} \mathrm{H}_{21} \mathrm{~N}_{4} \mathrm{O}_{5}$ 349.1506. Anal. Calcd for $\mathrm{C}_{16} \mathrm{H}_{20} \mathrm{~N}_{4} \mathrm{O}_{5} \cdot 2.2 \mathrm{H}_{2} \mathrm{O}$ : C 49.56, H 5.77, N 14.44. Found: C 49.08, H 5.54, N 14.02.

\subsection{5-(4-Hydroxy-3-iodophenyl)-5-[4-(2-hydroxyethyl)piperazin-1-yl]pryrimidine-2,4,6-trione (6)}

Compound $5 \mathrm{~d}(500 \mathrm{mg}, 1.44 \mathrm{mmol})$ was dissolved in methanol $(10 \mathrm{~mL})$ and treated with $58 \mathrm{mg}$ $(1.44 \mathrm{mmol})$ sodium hydroxide and $216 \mathrm{mg}(1.44 \mathrm{mmol})$ sodium iodide. The solution was cooled in an ice bath and $824 \mathrm{mg}(687 \mu \mathrm{L}, 1.44 \mathrm{mmol})$ sodium hypochlorite ( $13 \%$ active chlorine) were added dropwise over a period of $60 \mathrm{~min}$. The orange suspension was stirred in the ice bath for further $2 \mathrm{~h}$ until a nearly colorless solution had formed. The ice bath was removed and 2-3 crystals sodium 
thiosulfate were added at room temperature. The solution was acidified to $\mathrm{pH} 6.8$ by adding $1 \mathrm{M}$ $\mathrm{HCl}$ and extracted with ethylacetate $(3 \times 30 \mathrm{~mL})$. The combined extracts were washed with brine $(1 \times 30 \mathrm{~mL})$, dried $\left(\mathrm{MgSO}_{4}\right)$ and evaporated to dryness. Yield: $80 \mathrm{mg}(0.17 \mathrm{mmol} ; 12 \%) . \mathrm{Mp} 168-170{ }^{\circ} \mathrm{C}$ (decomposition). ${ }^{1} \mathrm{H}-\mathrm{NMR}\left(300 \mathrm{MHz}, \mathrm{DMSO}-d_{6}\right): \delta$ [ppm]: 11.50 (s, broad, $\left.2 \mathrm{H}\right), 7.60-6.69$ (m, $3 \mathrm{H}$, $\left.\mathrm{H}_{\text {Aryl }}\right), 4.34(\mathrm{~s}, 1 \mathrm{H}, \mathrm{OH}) 3.40-2.28\left(\mathrm{~m}, 12 \mathrm{H}, \mathrm{CH}_{2}\right) .{ }^{13} \mathrm{C}-\mathrm{NMR}\left(75.5 \mathrm{MHz}, \mathrm{DMSO}-d_{6}\right): \delta$ [ppm]: 169.87, 157.32, 149.35, 137.99, 129.10, 127.04, 115.37, 84.56, 73.25, 59.71, 58.27, 53.70, 47.11. MS (ESI-EM) m/e: 475.0467 $(\mathrm{M}+\mathrm{H})^{+}$calcd for $\mathrm{C}_{16} \mathrm{H}_{20} \mathrm{IN}_{4} \mathrm{O}_{5}$ 475.0473. Anal. Calcd for $\mathrm{C}_{16} \mathrm{H}_{19} \mathrm{IN}_{4} \mathrm{O}_{5} \cdot \mathrm{H}_{2} \mathrm{O}: \mathrm{C} 39.04, \mathrm{H} 4.30$, N 11.28. Found: C 39.47, H 4.23, N 11.21.

\subsection{General Procedure for Compounds $\mathbf{9}$ and $\mathbf{1 0}$}

A solution of 5-bromo-5-[4-(4-iodo-phenoxy)-phenyl]pyrimidine-2,4,6-trione 7 [8,12] in methanol (ca. $5-10 \mathrm{~mL} / \mathrm{mmol}$ ) was treated with 2.0 eq. of the appropriate piperazine (8 or 3-(piperazin-1-yl)propionic acid) and stirred at room temperature overnight. The colorless solids which precipitated after ca. $1 \mathrm{~h}$ were collected by suction and dried in vacuo. Compound $\mathbf{1 0}$ was further purified by silica gel column chromatography (EtOAc/ $\left.\mathrm{MeOH}(4 / 1, \mathrm{v} / \mathrm{v})+1 \% \mathrm{NEt}_{3}\right)$.

\subsubsection{5-[4-(2-Carboxyethyl)piperazin-1-yl]-5-[4-(4-iodophenoxy)phenyl]pyrimidine-2,4,6-trione (9)}

Yield: 83\%. Mp: 236-242 ${ }^{\circ} \mathrm{C}$ (decomposition). ${ }^{1} \mathrm{H}-\mathrm{NMR}\left(400 \mathrm{MHz}, \mathrm{DMSO}-d_{6}\right): \delta$ [ppm]: 9.31 (s, broad, $2 \mathrm{H}), 7.95\left(\mathrm{~d},{ }^{3} \mathrm{~J}=8.6 \mathrm{~Hz}, 2 \mathrm{H}, \mathrm{H}_{\text {Aryl }}\right), 7.72\left(\mathrm{~d},{ }^{3} \mathrm{~J}=9.0 \mathrm{~Hz}, 2 \mathrm{H}, \mathrm{H}_{\text {Aryl }}\right), 6.92\left(\mathrm{~d},{ }^{2} \mathrm{~J}=9.0 \mathrm{~Hz}\right.$, $\left.2 \mathrm{H}, \mathrm{H}_{\text {Aryl }}\right), 6.87\left(\mathrm{~d},{ }^{3} \mathrm{~J}=8.6 \mathrm{~Hz}, 2 \mathrm{H}, \mathrm{H}_{\text {Aryl }}\right), 3.16-3.09\left(\mathrm{~m}, 2 \mathrm{H}, \mathrm{CH}_{2}\right), 2.73-2.58\left(\mathrm{~m}, 8 \mathrm{H}, \mathrm{CH}_{2}\right), 2.51-2.44$ $\left(\mathrm{m}, 2 \mathrm{H}, \mathrm{CH}_{2}\right) .{ }^{13} \mathrm{C}-\mathrm{NMR}\left(100 \mathrm{MHz}, \mathrm{DMSO}-d_{6}\right): \delta[\mathrm{ppm}]: 173.80,164.31,158.77,151.62,150.29$, 138.66, 135.36, 131.05, 120.00, 118.05, 86.65, 85.42, 53.24, 49.46, 43.32, 40.53. MS (ESI-EM) m/e: 420.9687 $\left(\mathrm{M}-\mathrm{C}_{7} \mathrm{H}_{13} \mathrm{~N}_{2} \mathrm{O}_{2}\right)^{+}$calcd for $\mathrm{C}_{16} \mathrm{H}_{10} \mathrm{IN}_{2} \mathrm{O}_{4}$ 420.9685. Anal. Calcd for $\mathrm{C}_{23} \mathrm{H}_{23} \mathrm{IN}_{4} \mathrm{O}_{6} \cdot 2 \mathrm{H}_{2} \mathrm{O}: \mathrm{C} 44.96$, H 4.43, N 9.12. Found: C 45.16, H 4.70, N 9.52.

\subsubsection{5-(4-(2-(2-(2-(2-Fluoroethoxy)ethoxy)ethoxy)ethyl)piperazin-1-yl)-5-(4-(4-iodophenoxy)phenyl)-} pyrimidine-2,4,6-trione (10)

Yield: $8 \%$. Mp 176-177 ${ }^{\circ} \mathrm{C} .{ }^{1} \mathrm{H}-\mathrm{NMR}\left(300 \mathrm{MHz}, \mathrm{DMSO}-d_{6}\right) \delta[\mathrm{ppm}]: 9.28(\mathrm{~s}, 2 \mathrm{H}), 7.84(\mathrm{~d}$, $\left.{ }^{3} J=7.8 \mathrm{~Hz}, 2 \mathrm{H}, \mathrm{H}_{\text {Aryl }}\right), 7.64\left(\mathrm{~d},{ }^{3} J=7.8 \mathrm{~Hz}, 2 \mathrm{H}, \mathrm{H}_{\text {Aryl }}\right), 6.81\left(\mathrm{~d},{ }^{3} J=6.8 \mathrm{~Hz}, 2 \mathrm{H}, \mathrm{H}_{\text {Aryl }}\right), 6.76(\mathrm{~d}$, $\left.{ }^{3} \mathrm{~J}=6.8 \mathrm{~Hz}, 2 \mathrm{H}, \mathrm{H}_{\text {Aryl }}\right), 4.51\left(\mathrm{dt},{ }^{2} \mathrm{~J}_{\mathrm{H}, \mathrm{F}}=48.1 \mathrm{~Hz}, 2 \mathrm{H}, \mathrm{CH}_{2} \mathrm{~F}\right), 3.56-2.50\left(\mathrm{~m}, 22 \mathrm{H}, \mathrm{CH}_{2}\right) .{ }^{13} \mathrm{C}-\mathrm{NMR}$ $\left(75.5 \mathrm{MHz}, \mathrm{DMSO}-d_{6}\right): \delta$ [ppm]: 169.93, 158.40, 151.31, 149.89, 138.31, 135.00, 130.71, 119.61 117.75, 86.35, 85.13, $83.11\left(\mathrm{~d},\left.\right|^{1} J_{\mathrm{C}, \mathrm{F}} \mid=165.7 \mathrm{~Hz}\right), 70.54,70.39,70.12,69.76,69.57,68.15,56.71,49.62,42.98 .{ }^{19} \mathrm{~F}-\mathrm{NMR}$ (282 MHz, $\left.\mathrm{CDCl}_{3}\right): \delta[\mathrm{ppm}]:-216.61$. MS (ESI-EM) m/e: $685.1518(\mathrm{M}+\mathrm{H})^{+}$calcd for $\mathrm{C}_{28} \mathrm{H}_{35} \mathrm{FIN}_{4} \mathrm{O}_{7}$ 685.1529. The purity of $\mathbf{1 0}$ was determined by analytical gradient HPLC to be $>95 \%$ (system and conditions see Section 3.1), $\mathrm{t}_{R}=25.92 \pm 0.36 \mathrm{~min}(n=3)$.

\subsection{5-[4-(2-Carboxyethyl)piperazin-1-yl]-5-[4-(4-(tributylstannyl)phenoxy)phenyl]pyrimidine-2,4,6- trione (11)}

$\mathrm{PdCl}_{2}\left(\mathrm{PMePh}_{2}\right)_{2}(18 \mathrm{mg}, 30 \mu \mathrm{mol}, 3 \mathrm{~mol} \%)$ or $\mathrm{PdCl}_{2}(18 \mathrm{mg}, 100 \mu \mathrm{mol}, 10 \mathrm{~mol} \%), \mathrm{KOAc}$ (294 mg, $3.00 \mathrm{mmol}$, previously dried for several hours at $100{ }^{\circ} \mathrm{C}$ in vacuo before use) and $\mathrm{N}$-methyl-pyrrolidinone (NMP, $15 \mathrm{~mL}$ ) were mixed under an argon atmosphere [20]. Compound 9 $(578 \mathrm{mg}, 1.00 \mathrm{mmol})$ and tributyltin hydride $(582 \mathrm{mg}, 2.00 \mathrm{mmol})$ or hexabutylditin $(870 \mathrm{mg}, 1.50 \mathrm{mmol})$ were added and the mixture was heated to $110{ }^{\circ} \mathrm{C}$ for $10-15 \mathrm{~h}$. The progress of the reaction was monitored by HPLC (system and conditions see Section 3.1). The retention times $t_{R}$ were: $t_{R}(9)$ : $34.15 \pm 1.38 \mathrm{~min}(n=10), \mathrm{t}_{R}(\mathbf{1 1}): 40.83 \pm 1.17 \mathrm{~min}(n=6)$. When the conversion was complete, the hot black reaction mixture was filtered through a pad of Celite by suction and the filter cake was washed with a small amount of NMP. The orange filtrate was stored at $-30{ }^{\circ} \mathrm{C}$ overnight. The beige solid which precipitated upon cooling was isolated by suction. When there was no precipitation, the volatile components of the filtrate were removed by short-path distillation. The solid residue was taken up in hot methanol and insoluble components were filtered off. The solvent was removed in vacuo and the residue was treated with acetone. Yield: $208 \mathrm{mg}(0.28 \mathrm{mmol}, 28 \%)$. The purity of the product 
was $>95 \%$ as determined by analytical gradient HPLC. Mp: $285-286{ }^{\circ} \mathrm{C}$ (decomposition). ${ }^{1} \mathrm{H}-\mathrm{NMR}$ (400 MHz, DMSO- $\left.d_{6}\right): \delta$ [ppm]: 7.89-7.12 (m, 8 H, H Aryl), 3.56-1.94 (m, 12 H, CH $), 1.77-1.67$ (m, $6 \mathrm{H}$, $\left.\mathrm{CH}_{2}\right), 1.56-1.44\left(\mathrm{~m}, 6 \mathrm{H}, \mathrm{CH}_{2}\right), 1.25-1.20\left(\mathrm{~m}, 6 \mathrm{H}, \mathrm{CH}_{2}\right), 1.06\left(\mathrm{t},{ }^{3} \mathrm{~J}=8.3 \mathrm{~Hz}, 9 \mathrm{H}, \mathrm{CH}_{3}\right)$. MS (ESI-EM) m/e: $585.1847\left(\mathrm{M}-\mathrm{C}_{7} \mathrm{H}_{13} \mathrm{~N}_{2} \mathrm{O}_{2}\right)^{+}$calcd for $\mathrm{C}_{28} \mathrm{H}_{37} \mathrm{~N}_{2} \mathrm{O}_{4} \mathrm{Sn} 585.1775$.

\subsection{General Methods. Radiochemistry}

N. c. a $\left[{ }^{124} \mathrm{I}\right] \mathrm{NaI}$ was provided by Department of Nuclear Medicine, University Hospital Essen, University Duisburg-Essen, Germany. Typical radioactivities used for the radioiodination were $134 \pm 48 \mathrm{MBq}\left[{ }^{124} \mathrm{I}\right] \mathrm{NaI}$ in $50 \pm 18 \mu \mathrm{L}$ in $0.01 \mathrm{~N} \mathrm{NaOH}$. N. c. a. $\left[{ }^{123} \mathrm{I}\right] \mathrm{NaI}$ was purchased from GE Healthcare Buchler GmbH \& Co KG (Braunschweig, Germany). Typical radioactivities used for the radioiodination were $136 \pm 63 \mathrm{MBq}\left[{ }^{123} \mathrm{I}\right] \mathrm{NaI}$ in $10 \pm 3 \mu \mathrm{L}$ in $0.05 \mathrm{~N} \mathrm{NaOH}$. Separation, purification and analyses of the radiochemical yields and the radiochemical purities of all radioiodinated compounds were performed by a gradient radio-HPLC chromatograph system (HPLC A) using a Knauer K-500 and a Latek P 402 pump, a Knauer K-2000 UV-detector $(\lambda=254 \mathrm{~nm})$ a Crismatec NaI(Tl) Scintibloc 51 SP51 $\gamma$-detector and a RP-HPLC Nucleosil column 100-5 C-18 (250 mm $\times 4.6 \mathrm{~mm})$, a corresponding precolumn $(20 \mathrm{~mm} \times 4.0 \mathrm{~mm})$. Sample injection was carried out using a Rheodyne injector block (type 7125 incl. $200 \mu \mathrm{L}$ loop). The recorded data were processed by the NINA version 4.9 software (GE Medical Systems-Functional Imaging GmbH, Münster, Germany). Separation and purification of the radiosynthesized compounds were-unless specified otherwise-performed by radio-HPLC (HPLC A, see above) using a Nucleosil 100-10 C18 column $(250 \mathrm{~mm} \times 8 \mathrm{~mm})$. The recorded data were processed by the NINA version 4.9 software. The radiochemical purities and the specific activities were determined using a radio-HPLC system (HPLC B) composed of a Sykam S1021 pump, a Knauer K-2501 UV-detector $(\lambda=254 \mathrm{~nm})$, a Crismatec NaI(Tl) Scintibloc 51 SP51 $\gamma$-detector, a Nucleosil 100-3 C18 column (200 mm $\times 3 \mathrm{~mm}$ ), a VICI injector block (type C1 incl. $20 \mu \mathrm{L}$ loop) and the GINA Star version 4.07 radiochromatography software (raytest Isotopenmeßgeräte GmbH, Straubenhardt, Germany). Radio-TLC was analyzed using a miniGITA TLC-Scanner (raytest Isotopenmeßgeräte $\mathrm{GmbH}$, Straubenhardt, Germany).

\subsection{5-[4-(2-Carboxyethyl)piperazin-1-yl]-5-[4-(4-[123/124 I]-iodophenoxy)phenyl]pyrimidine-2,4,6-trione $([123 / 124 I] 9)$}

In a conical glass vial $89 \mu \mathrm{g}(0.12 \mu \mathrm{mol})$ stannyl precursor 11 in $39 \mu \mathrm{L} \mathrm{MeOH}$ was added to n. c. a. $\left[{ }^{123} \mathrm{I}\right] \mathrm{NaI}$ or $\left[{ }^{124} \mathrm{I}\right] \mathrm{NaI}$. The radiosynthesis was started by addition of $34 \mathrm{mg}(0.14 \mu \mathrm{mol})$ chloroamine-T hydrate in $39 \mu \mathrm{L} 0.1 \mathrm{M} \mathrm{K}_{2} \mathrm{HPO}_{4}$ buffer ( $\mathrm{pH} 7.34$ ). The mixture was vortexed for $10 \mathrm{~s}$ and allowed to stand for $5 \mathrm{~min}$ at room temperature. To quench the reaction $50 \mu \mathrm{L}$ of a $10 \% \mathrm{Na}_{2} \mathrm{~S}_{2} \mathrm{O}_{5}$ solution (in water for injection) was added and the mixture was vortexed again for $10 \mathrm{~s}$. After $10 \mathrm{~min}$ the quenched reaction solution was injected onto the HPLC column (see Section 3.11. HPLC A) to isolate the fraction of the radiolabelled product [ $\left.{ }^{124} \mathrm{I}\right] 9$ (HPLC conditions: eluent $\mathrm{A}: \mathrm{CH}_{3} \mathrm{CN} / \mathrm{H}_{2} \mathrm{O} / \mathrm{TFA} 950 / 50 / 1, \mathrm{v} / \mathrm{v} / \mathrm{v}$, eluent B: $\mathrm{CH}_{3} \mathrm{CN} / \mathrm{H}_{2} \mathrm{O} / \mathrm{TFA} 50 / 950 / 1$, v/v/v; gradient: from $92 \%$ B to $40 \%$ B within $45 \mathrm{~min}, 5 \mathrm{~min}$ constant at $40 \% \mathrm{~B}$, and from $40 \% \mathrm{~B}$ to $92 \% \mathrm{~B}$ within $5 \mathrm{~min}$ at a flow rate of $2.0 \mathrm{~mL} / \mathrm{min}, \lambda=254 \mathrm{~nm}$; $\mathrm{t}_{R}\left(\right.$ stannyl precursor 11) $\left.=40.80 \pm 0.81 \min (n=3), \mathrm{t}_{R}\left(\left[{ }^{124} \mathrm{I}\right] 9\right)=32.75 \pm 2.13 \mathrm{~min}(n=3)\right)$. The product fraction was evaporated to dryness and redissolved in $0.9 \% \mathrm{NaCl}(200 \mu \mathrm{L})$. The decay-corrected radiochemical yield (after evaporation) was $28 \pm 7 \%(n=6)$ for $\left[{ }^{123} \mathrm{I}\right] 9$ and $44 \pm 6 \%(n=3)$ for [ $\left.{ }^{124} \mathrm{I}\right] 9$, respectively. An aliquot $(50 \mu \mathrm{L})$ was taken for analytical radio-HPLC. The radiochemical purities were $95 \pm 3 \%$ and $93 \pm 5 \%$ for $\left[{ }^{123} \mathrm{I}\right] 9$ and $\left[{ }^{124} \mathrm{I}\right] 9$, and the molar activities were $0.2-6.3 \mathrm{GBq} / \mu \mathrm{mol}$ and 0.4-14.0 GBq/ $\mu \mathrm{mol}$, respectively. The identity of $\left[{ }^{123} \mathrm{I}\right] 9$ and $\left[{ }^{124} \mathrm{I}\right] 9$ was proven by HPLC using the non-radioactive analog 9.

\subsection{In Vitro Enzyme Inhibition Assays}

The synthetic fluorometric substrate (7-methoxycoumarin-4-yl) acetyl pro-Leu-Gly-Leu-(3-(2,4dinitrophenyl)-L-2,3-diamino-propionyl)-Ala-Arg- $\mathrm{NH}_{2}$ ( $\mathrm{R}$ \& D Systems, Minneapolis, MN, USA) 
was used to assay activated MMP-2, MMP-8, MMP-9 and MMP-13 as described previously [21]. The inhibitions of human active MMP-2, MMP-8, MMP-9 MMP-13 and MMP-14 (only 9) by the barbituric acid derivatives 9 and 10, of human active MMP-2 and MMP-9 by 5a, 5b and 6 were assayed by preincubating MMP-2, MMP-3, MMP-8, MMP-9, MMP-13 or MMP-14 (each at $2 \mathrm{nM}$ ) and inhibitor compounds at varying concentrations $(10 \mathrm{pM}-1 \mathrm{mM})$ in $50 \mathrm{mM}$ Tris $\cdot \mathrm{HCl}, \mathrm{pH} 7.5$, containing $0.2 \mathrm{M}$ $\mathrm{NaCl}, 5 \mathrm{mM} \mathrm{CaCl}_{2}, 20 \mu \mathrm{M} \mathrm{ZnSO} 4$ and $0.05 \%$ Brij 35 at $37{ }^{\circ} \mathrm{C}$ for $30 \mathrm{~min}$. An aliquot of substrate (10 $\mu \mathrm{L}$ of a $50 \mu \mathrm{M}$ solution) was then added to $90 \mu \mathrm{L}$ of the preincubated MMP/inhibitor mixture, and the fluorescence was determined at $37^{\circ} \mathrm{C}$ by following product release with time. The fluorescence changes were monitored using a Fusion Universal Microplate Analyzer (Packard Bioscience, Boston, MA, USA) with excitation and emission wavelengths set to 330 and $390 \mathrm{~nm}$, respectively. Reaction rates were measured from the initial $10 \mathrm{~min}$ of the reaction profile where product release was linear with time and plotted as a function of inhibitor dose. From the resulting inhibition curves, the $\mathrm{IC}_{50}$ values for each inhibitor were calculated by non-linear regression analysis, performed using the Grace 5.1.8 software (Linux).

\section{Conclusions}

Starting from the lipophilic preclincal research tracer $\left[{ }^{125} \mathrm{I}\right] \mathbf{1 2}$ (clogD 3.53, Table 2), that was already developed by our group [12], we intended to develop a more hydrophilic radioiodinated barbiturate-based MMP-targeted tracer for the potential non-invasive visualization of activated MMPs in vivo. This was achieved by the substitution of the hydroxy group of $\mathbf{1 2}$ by a carboxy group yielding derivative 9 with a hydrophilic shift compared to 12 (clogD 0.92 vs. 3.53). Similar to 12 carboxylic acid 9 represents a very potent inhibitor of MMP-2 and -9 $\left(\mathrm{IC}_{50}(\mathrm{MMP}-2)=29 \mathrm{nM}, \mathrm{IC}_{50}\right.$ $($ MMP-9 $)=1.3 \mathrm{nM})$. Therefore radioiodinated analogues $\left[{ }^{123 / 124} \mathrm{I}\right] 9$ were successfully synthesized for further in vivo evaluations with SPECT and PET.

Acknowledgments: This work was supported by grants from the German Research Foundation (Deutsche Forschungsgemeinschaft (DFG)), Collaborative Research Centre CRC 656, Münster, Germany (CRC 656 projects A02, B01 and Z05). We thank Prof. Wolfgang Brandau, Department of Nuclear Medicine, University Hospital Essen, Essen, Germany, for providing [ $\left.{ }^{124} \mathrm{I}\right] \mathrm{NaI}$. We thank Sandra Höppner and Sven Fatum for excellent technical assistance, Heinrich Luftmann and Klaus Bergander, Organic Chemistry Institute, WWU Münster for performing mass spectrometry and NMR spectroscopy, respectively. Many thanks also to Werner Henkel for his temporarily work in our laboratories.

Author Contributions: H.J.B., K.K. and S.W. conceived and designed the experiments; H.J.B., K.K. and S.W. performed the experiments; H.J.B., K.K., M.S. and S.W. analyzed the data; H.J.B. and S.W. wrote the paper.

Conflicts of Interest: The authors declare no conflict of interest.

\section{References}

1. Schäfers, M.; Schober, O.; Hermann, S. Matrix-metalloproteinases as imaging targets for inflammatory activity in atherosclerotic plaques. J. Nucl. Med. 2010, 51, 663-666. [CrossRef] [PubMed]

2. Dahl, G.; Akerud, T. Pharmacokinetics and the drug-target residence time concept. Drug. Discov. Today 2013, 18, 697-707. [CrossRef] [PubMed]

3. Chen, K.; Chen, X. Design and development of molecular imaging probes. Curr. Top. Med. Chem. 2010, 10, 1227-1236. [CrossRef] [PubMed]

4. Wagner, S.; Breyholz, H.J.; Faust, A.; Höltke, C.; Levkau, B.; Schober, O.; Schäfers, M.; Kopka, K. Molecular imaging of matrix metalloproteinases in vivo using small molecule inhibitors for SPECT and PET. Curr. Med. Chem. 2006, 13, 2819-2838. [CrossRef] [PubMed]

5. Matusiak, N.; Van Waarde, A.; Bischoff, R.; Oltenfreiter, R.; Van de Wiele, C.; Dierckx, R.A.; Elsinga, P.H. Probes for non-invasive matrix metalloproteinase-targeted imaging with PET and SPECT. Curr. Pharm. Des. 2013, 19, 4647-4672. [CrossRef] [PubMed]

6. Van der Wiele, C.; Oltenfreiter, R. Imaging probes targeting matrix metalloproteinases. Cancer Biother. Radiopharm. 2006, 21, 409-417. [CrossRef] [PubMed] 
7. MacPherson, L.J.; Bayburt, E.K.; Capparelli, M.P.; Carroll, B.J.; Goldstein, R.; Justice, M.R.; Zhu, L.; Hu, S.I.; Melton, R.A.; Fryer, L.; et al. Discovery of CGS 27023A, a non-peptidic, potent, and orally active stromelysin inhibitor that blocks cartilage degradation in rabbits. J. Med. Chem. 1997, 40, 2525-2532. [CrossRef] [PubMed]

8. Grams, F.; Brandstetter, H.; D'Alo, S.; Geppert, D.; Krell, H.W.; Leinert, H.; Livi, V.; Menta, E.; Oliva, A.; Zimmermann, G. Pyrimidine-2,4,6-Triones: A new effective and selective class of matrix metalloproteinase inhibitors. Biol. Chem. 2001, 382, 1277-1285. [CrossRef] [PubMed]

9. Brandstetter, H.; Grams, F.; Glitz, D.; Lang, A.; Huber, R.; Bode, W.; Krell, H.W.; Engh, R.A. The 1.8-A crystal structure of a matrix metalloproteinase 8-barbiturate inhibitor complex reveals a previously unobserved mechanism for collagenase substrate recognition. J. Biol. Chem. 2001, 276, 17405-17412. [CrossRef] [PubMed]

10. Foley, L.H.; Palermo, R.; Dunten, P.; Wang, P. Novel 5,5-disubstituted-pyrimidine-2,4,6-triones as selective MMP inhibitors. Bioorg. Med. Chem. Lett. 2001, 23, 969-972. [CrossRef]

11. Maquoi, E.; Sounni, N.E.; Devy, L.; Olivier, F.; Frankenne, F.; Krell, H.W.; Grams, F.; Foidart, J.M.; Noël, A. Anti-invasive, antitumoral, and antiangiogenic efficacy of a pyrimidine-2,4,6-trione derivative, an orally active and selective matrix metalloproteinases inhibitor. Clin. Cancer Res. 2004, 10, 4038-4047. [CrossRef] [PubMed]

12. Breyholz, H.J.; Schäfers, M.; Wagner, S.; Höltke, C.; Faust, A.; Rabeneck, H.; Levkau, B.; Schober, O.; Kopka, K. C-5-disubstituted barbiturates as potential molecular probes for noninvasive matrix metalloproteinase imaging. J. Med. Chem. 2005, 48, 3400-3409. [CrossRef] [PubMed]

13. Faust, A.; Waschkau, B.; Waldeck, J.; Höltke, C.; Breyholz, H.J.; Wagner, S.; Kopka, K.; Heindel, W.; Schäfers, M.; Bremer, C. Synthesis and evaluation of a novel fluorescent photoprobe for imaging matrix metalloproteinases. Bioconjug. Chem. 2008, 19, 1001-1008. [CrossRef] [PubMed]

14. Breyholz, H.J.; Faust, A.; Waschkau, B.; Wagner, S.; Höltke, C.; Waldeck, J.; Brandau, W.; Bremer, C.; Schober, O.; Schäfers, M.; et al. Pyrimidine-2,4,6-triones as Model Probes for the in vivo Molecular Imaging of Activated MMPs-A Dual Approach for Radiotracer and Optical Imaging. Eur. J. Nucl. Med. Mol. Imaging 2008, 35 (Suppl. 2), S316.

15. Breyholz, H.J.; Wagner, S.; Faust, A.; Riemann, B.; Höltke, C.; Hermann, S.; Schober, O.; Schäfers, M.; Kopka, K. Radiofluorinated pyrimidine-2,4,6-triones as molecular probes for noninvasive MMP-targeted imaging. ChemMedChem 2010, 5, 777-789. [CrossRef] [PubMed]

16. Schrigten, D.; Breyholz, H.J.; Wagner, S.; Hermann, S.; Schober, O.; Schäfers, M.; Haufe, G.; Kopka, K. A new generation of radiofluorinated pyrimidine-2,4,6-triones as MMP-targeted radiotracers for positron emission tomography. J. Med. Chem. 2012, 55, 223-232. [CrossRef] [PubMed]

17. Claesener, M.; Schober, O.; Wagner, S.; Kopka, K. Radiosynthesis of a ${ }^{68}$ Ga labeled matrix metalloproteinase inhibitor as a potential probe for PET imaging. Appl. Radiat. Isot. 2012, 70, 1723-1728. [CrossRef] [PubMed]

18. Faust, A.; Hermann, S.; Schäfers, M.; Höltke, C. Optical imaging probes and their potential contribution to radiotracer development. Nuklearmedizin 2016, 55, 51-62. [PubMed]

19. Wasserman, H.H.; Hlasta, D.J.; Tremper, A.W.; Wu, J.S. Application of new $\beta$-lactam syntheses to the preparation of $( \pm)$-3-aminonocardicinic acid. J. Org. Chem. 1981, 46, 2999-3011. [CrossRef]

20. Wasikiewicz, W.; Rokicki, G.; Kielkiewicz, J.; Paulus, E.F.; Boehmer, V. Head-to-tail connected double calix[4]arenes. Mon. Chem. 1997, 128, 863-879. [CrossRef]

21. Schäfers, M.; Riemann, B.; Kopka, K.; Breyholz, H.J.; Wagner, S.; Schäfers, K.P.; Law, M.P.; Schober, O.; Levkau, B. Scintigraphic Imaging of Matrix Metalloproteinase Activity in the Arterial Wall In Vivo. Circulation 2004, 109, 2554-2559. [CrossRef] [PubMed]

(C) 2017 by the authors. Licensee MDPI, Basel, Switzerland. This article is an open access article distributed under the terms and conditions of the Creative Commons Attribution (CC BY) license (http:/ / creativecommons.org/licenses/by/4.0/). 